\title{
Effect of supplementing feed with oregano and/or $\alpha$-tocopheryl acetate on growth of broiler chickens and oxidative stability of meat
}

\author{
I.A. Giannenas, P. Florou-Paneri, N.A. Botsoglou', \\ E. Christaki and A.B. Spais \\ Laboratory of Animal Nutrition, \\ Faculty of Veterinary Medicine, Aristotle University \\ 54006 Thessaloniki, Greece
}

(Received 30 December 2004; Revised version 21 February 2005; accepted 4 August 2005)

\begin{abstract}
An experiment was carried out to examine the effect of supplementing feed with oregano and/or $\alpha$-tocopheryl acetate on growth performance of broiler chickens and the oxidative stability of breast and thigh meat. A total of 6300 one-day old Cobb-500 chickens were randomly allocated into 7 equal groups with three subgroups of 150 males and 150 females each. One of the groups was given a basal diet containing $30 \mathrm{mg} \alpha$-tocopheryl acetate $/ \mathrm{kg}$ feed (negative control group), whereas the other six groups were administered the basal diet supplemented further with dehydrated oregano plants at 5 $\mathrm{g} / \mathrm{kg}$ (OR5 group) and $10 \mathrm{~g} / \mathrm{kg}$ (OR10 group), dehydrated oregano plants at 5 or $10 \mathrm{~g} / \mathrm{kg}$ plus 170 $\mathrm{mg} / \mathrm{kg} \alpha$-tocopheryl acetate (OR5-TOC and OR10-TOC group, respectively), $\alpha$-tocopheryl acetate at $170 \mathrm{mg} / \mathrm{kg}$ (TOC group), and flavomycin at $4 \mathrm{mg} / \mathrm{kg}$ plus lasalocid at $75 \mathrm{mg} / \mathrm{kg}$ (FLA-LAS positive control group). After 42 days of feeding, values of body weight, daily weight gain and feed conversion ratio showed that oregano given as single supplement at the level of $5 \mathrm{~g} / \mathrm{kg}$ or in combination with $\alpha$-tocopheryl acetate could serve as an alternative to the approved feed additives flavomycin and lasalocid, exerting a growth-promoting effect. Feed supplementation with oregano decreased malondialdehyde values in meat samples compared with the control, the supplementation level of 5 $\mathrm{g} / \mathrm{kg}$ being more effective in retarding lipid oxidation compared with $10 \mathrm{~g} / \mathrm{kg}$. The antioxidant activity offered by oregano was, however, inferior to that exhibited by $\alpha$-tocopheryl acetate supplementation, while the antioxidant activity presented by the combination of $5 \mathrm{~g} / \mathrm{kg}$ oregano and $\alpha$-tocopheryl acetate was higher than that presented by $\alpha$-tocopheryl acetate when supplemented alone or in combination with $10 \mathrm{~g} / \mathrm{kg}$ oregano. Thigh meat samples were found to be more susceptible to oxidation compared with breast meat, although the latter contained $\alpha$-tocopherol at markedly lower levels.
\end{abstract}

KEY WORDS: oregano plants, broilers, nutrition, performance, oxidative stability, chicken meat

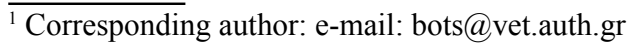




\section{INTRODUCTION}

The poultry industry in Europe plays a major role in the meat market due mainly to the desirable nutritional characteristics of poultry meat. These include a low lipid content and relatively high concentrations of polyunsaturated fatty acids that can be further increased by specific dietary strategies (Hargis and Van Elswyk, 1993).

The poultry industry would not achieve its current high productivity levels, measured as rapid growth rate, low feed conversion ratio and low mortality, without the high genetic potential of broilers, optimum diet specifications, and the use of antimicrobial feed additives. However, the increasing pressure of consumers for more healthy food has recently prompted European countries to ban certain feed additives, including antibiotics and anticoccidial substances (European Commission Regulations, 1998). It is now generally accepted that the use of antimicrobial feed additives might potentially affect human health due to emergence of antibiotic-resistant microorganisms in food animals (Wegener et al., 1998).

If antibacterial feed additives are withdrawn from use, alternative feeding strategies should probably be introduced to offset any possible adverse effects on production. There is, therefore, a growing interest in the identification and evaluation of alternatives to traditional feed additives that would be closer to environmentally friendly farming practices and satisfy both producer and consumer expectations.

In recent years, extracts or essential oils from several herbal plants including rosemary and sage (Lopez-Bote et al., 1998), tea (Tang et al., 2000), and oregano (Botsoglou et al., 2002a,b, 2003a) have attracted research interest asalternative feed supplements to antimicrobial feed additives. They have all been also shown to have the potential to increase the antioxidant capacity of poultry meat when added to feeds. Published information on the possible use of intact herbal plants as feed supplements is still, however, rather limited.

In a previous study conducted in our laboratory on the modulation of Eimeria tenella infection by various aromatic plants of the Greek flora, we found that dehydrated oregano (Origanum vulgare subsp. hirtum) plants and Olympus tea (Sideritis scardica) plants, both members of the Labiatae family, exhibited moderate coccidiostatic action against E. tenella when they were incorporated into chicken diets (Florou-Paneri et al., 2004; Giannenas et al., 2004). The purpose of this study was to investigate the effect of feed supplementation with oregano and/or $\alpha$-tocopheryl acetate on the growth performance of broiler chickens and the oxidative stability of breast and thigh meat. 


\section{MATERIAL AND METHODS}

\section{Animals and dietary treatments}

A total of 6300 day-old Cobb-500 chickens randomly allocated into 7 equal groups with three subgroups of 150 males and 150 females each, was used in this study. All birds were cared for in accordance with the Guide for the Care and Use of Laboratory Animals (Committee on Care and Use of Laboratory Animals, 1996). The chickens were housed in a commercial broiler chicken farm in floor pens with wood shaving litter. During the experimental period that lasted 42 days, the temperature was gradually decreased from $32^{\circ} \mathrm{C}$ on day 1 to $22^{\circ} \mathrm{C}$ on day 21 and kept constant thereafter. The lighting regimen provided $23 \mathrm{~h}$ of light per day. The birds were vaccinated against Newcastle disease and infectious bronchitis on day 10 of age using Hitchner B1 and Massachusetts H120 strains, respectively, and against Gumboro disease on day 17 of age using strain D-78.

One of the groups was given basal diets containing $30 \mathrm{mg} \alpha$-tocopheryl acetate $/ \mathrm{kg}$ feed. This group served as the negative control group for the evaluation of growth performance of chickens, and as the control group for the lipid oxidation studies. The other six groups were administered the basal diets supplemented further with dehydrated oregano plants at $5 \mathrm{~g} / \mathrm{kg}$ (OR5 group) and $10 \mathrm{~g} / \mathrm{kg}$ (OR10 group), dehydrated oregano plants at $5 \mathrm{~g} / \mathrm{kg}$ plus an extra $170 \mathrm{mg} / \mathrm{kg} \alpha$-tocopheryl acetate (OR5-TOC group), dehydrated oregano plants at $10 \mathrm{~g} / \mathrm{kg}$ plus an extra $170 \mathrm{mg} / \mathrm{kg} \alpha$-tocopheryl acetate (OR10-TOC group), $\alpha$-tocopheryl acetate at an extra of $170 \mathrm{mg} / \mathrm{kg}$ (TOC group), and flavomycin at $4 \mathrm{mg} / \mathrm{kg}$ plus lasalocid at $75 \mathrm{mg} / \mathrm{kg}$ (FLA-LAS group). The FLA-LAS group served as the positive control group for the evaluation of growth performance of chickens.

Table 1 presents the ingredients and the composition of the starter, grower and finisher basal diets that were in mash form. The dehydrated oregano plants consisted of flowered tops, leaves, stems and stalks of Origanum vulgare subsp. hirtum plants (Ecopharm Hellas, SA, Kilkis, Greece) that had been ground to pass a $2 \mathrm{~mm}$ screen. According to the supplier, the oregano plants contained $1.22 \%$ carvacrol and $0.07 \%$ thymol. Proximate analysis showed that the plants also contained, $\%$ : moisture 8.9 , crude protein 13.3 , crude fat 4.1 , crude fibre 19.0 , and ash 9.1. Diets and drinking water were offered to birds ad libitum. 
TABLE 1

Composition of basal diets, $\mathrm{g} / \mathrm{kg}$

\begin{tabular}{|c|c|c|c|}
\hline \multirow{3}{*}{ Indices } & \multicolumn{3}{|c|}{ Diets } \\
\hline & starter & grower & finisher \\
\hline & $(1-14 d)$ & $(15-28 \mathrm{~d})$ & $(29-42 \mathrm{~d})$ \\
\hline \multicolumn{4}{|l|}{ Ingredients } \\
\hline wheat grains & 573.0 & 557.0 & 604.0 \\
\hline soyabean meal & 311.0 & 303.0 & 278.0 \\
\hline soyabean oil & 25.0 & 55.0 & 31.0 \\
\hline vegetable fat & 0.0 & 0.0 & 25.0 \\
\hline brewer's yeast & 25.0 & 25.0 & 12.5 \\
\hline herring meal & 25.0 & 15.0 & 5.0 \\
\hline maize gluten feed & 10.0 & 10.0 & 10.0 \\
\hline limestone, pulverized & 12.6 & 14.7 & 16.1 \\
\hline dicalcium phosphate & 7.3 & 8.6 & 8.9 \\
\hline biolysine -BASF & 3.0 & 3.3 & 2.4 \\
\hline DL-methionine & 2.6 & 2.9 & 2.0 \\
\hline sodium chloride, iodized & 2.6 & 2.6 & 2.2 \\
\hline $\begin{array}{l}\text { natugrain-BASF } \\
\quad \text { (arabinoxylanases plus glucanases) }\end{array}$ & 0.2 & 0.2 & 0.2 \\
\hline vitamin premix ${ }^{1}$ & 2.2 & 2.2 & 2.2 \\
\hline trace-mineral premix ${ }^{2}$ & 0.5 & 0.5 & 0.5 \\
\hline \multicolumn{4}{|l|}{ Chemical analysis } \\
\hline dry matter & 891.3 & 892.2 & 901.3 \\
\hline crude protein $(\mathrm{N} \times 6.25)$ & 23.2 & 22.1 & 20.2 \\
\hline crude fat & 54.4 & 73.1 & 75.2 \\
\hline crude fibre & 32.1 & 35.1 & 36.2 \\
\hline ash & 54.3 & 55.2 & 56.3 \\
\hline \multicolumn{4}{|l|}{ Calculated analysis } \\
\hline $\mathrm{Ca}$ & 9.3 & 9.3 & 9.0 \\
\hline $\mathrm{P}$ (total) & 7.0 & 7.0 & 6.8 \\
\hline lysine & 14.0 & 13.0 & 12.0 \\
\hline methionine + cystine & 11.2 & 10.1 & 9.2 \\
\hline metabolizable energy, $\mathrm{kcal} / \mathrm{kg}$ & 3060.0 & 3160.0 & 3220.0 \\
\hline
\end{tabular}

${ }^{1}$ supplying per kg feed: vit. A 14,000 IU, vit. $\mathrm{D}_{3} 5,000 \mathrm{IU}$; $\mathrm{mg}$ : vit. E 30 , vit. $\mathrm{K}$ 1, thiamin 1 , riboflavin 5 , pyridoxine 3 , vit. $\mathrm{B}_{12} 0.02$, niacin 30 , pantothenic acid 10 , folic acid 0.8 , biotin 0.05 , vit. C 10, choline chloride 480

${ }^{2}$ supplying per kg feed, mg: Zn 100, Mn 120, Fe 20, Cu 15, Co 0.2, I 1, Se 0.3

\section{Growth performance}

To evaluate growth performance, thirty chickens from each subgroup were taken at random at 1, 7, 14, 21, 35 and 42 days of age, and weighed individually for estimation of body weight gain. Four hours prior to weighing, dietswere removed and feed intake within each subgroup was also determined. Feed conversion ratio 
values were calculated weekly as the ratio of feed intake to weight gain. Mortality was recorded daily in each subgroup.

\section{Sampling procedure}

At 42 days of age, the chickens were slaughtered, and carcasses from 12 male and 12 female birds were randomly taken from each subgroup and trimmed for breast and thigh muscle tissue by removing skin, bones, connective tissue and subcutaneous fat. Following trimming, breast and thigh muscle tissues were sampled for iron-induced and refrigerated-storage-induced lipid oxidation, and determination of $\alpha$-tocopherol concentrations.

\section{Iron-induced and refrigerated-storage-induced lipid oxidation}

Iron-induced lipid oxidation of breast and thigh muscle samples was carried out according to Botsoglou et al. (2002a) with minor modifications. In brief, 1-g samples were homogenized (Ultra-Turrax, IKA-R - Labortechnik, Staufen, Germany) for $15 \mathrm{~s}$ with $0.5 \mathrm{ml} 5 \mathrm{mM} \mathrm{FeSO}_{4} 7 \mathrm{H}_{2} \mathrm{O}$ and $0.5 \mathrm{ml} 2 \mathrm{mM}$ ascorbic acid. Three portions from each homogenate were immediately subjected to ironinduced lipid oxidation by incubation at $37^{\circ} \mathrm{C}$ for 90,180 , or $270 \mathrm{~min}$. Following incubation, all three incubated portions along with a fourth non-incubated portion from each homogenate were immediately analysed for their malondialdehyde (MDA) content.

To study refrigerated-storage-induced lipid oxidation, breast and thigh muscle samples were minced, wrapped in transparent oxygen-permeable polyvinyl chloride film $\left(6000-8000 \mathrm{~cm}^{3} / \mathrm{m}^{2} 24 \mathrm{~h}\right)$, and placed in a non-illuminated refrigerated cabinet at $4^{\circ} \mathrm{C}$ for a total of 9 days. The progress of lipid oxidation was determined at $0,3,6$ and 9 days of storage on the basis of the MDA content.

Malondialdehyde, the compound used as an index of lipid peroxidation, was determined by a selective third-order derivative spectrophotometric method (Botsoglou et al., 1994). In brief, samples were homogenized in the presence of $8 \mathrm{ml}$ of $5 \%$ aqueous trichloroacetic acid and $5 \mathrm{ml}$ of $0.8 \%$ butylated hydroxytoluene in hexane, and the mixture was centrifuged. The top layer was discarded, and a $2.5-\mathrm{ml}$ aliquot from the bottom layer was mixed with $1.5 \mathrm{ml}$ of $0.8 \%$ aqueous 2-thiobarbituric acid to be further incubated at $70^{\circ} \mathrm{C}$ for $30 \mathrm{~min}$. Following incubation, the mixture was cooled under tap water and submitted to conventional spectrophotometry (Shimadzu, Model UV-160A, Tokyo, Japan) in the range of $400-650 \mathrm{~nm}$. Third-order derivative spectra were produced by digital differentiation of the normal spectra using a derivative wavelength difference setting of $21 \mathrm{~nm}$. The concentration of MDA in analysed samples was calculated 
on the basis of the height of the third-order derivative peak at $521.5 \mathrm{~nm}$ by referring to slope and intercept data of the computed least-squares fit of a standard calibration curve prepared using 1,1,3,3-tetraethoxypropane.

\section{Chemicals}

All chemicals used for lipid oxidation studies and analysis of $\alpha$-tocopherol, were of analytical-grade. Butylated hydroxytoluene, 2-thiobarbituric acid, ascorbic acid, $\alpha$-tocopherol reference standard, $\mathrm{FeSO}_{4} 7 \mathrm{H}_{2} \mathrm{O}$, and 1,1,3,3tetraethoxy-propane, the precursor of malondialdehyde, were obtained from Sigma Chemical Co. (St. Louis, MO). Trichloroacetic acid, pyrocatechol, hexane, methanol, acetonitrile, hydrochloric acid, and sodium hydroxide were purchased from Merck (Darmstadt, Germany) whereas $\alpha$-tocopheryl acetate from BASF Ltd. (Ludwigshafen, Germany).

\section{Analysis of $\alpha$-tocopherol in muscle and feed samples}

For the extraction of $\alpha$-tocopherol, samples ( $0.5 \mathrm{~g})$ were homogenized with 5 $\mathrm{ml}$ of a saturated methanol solution of $\mathrm{KOH}$ in the presence of $100 \mu$ pyrocatechol solution $(200 \mathrm{mg} / \mathrm{ml})$ and then immersed in a water bath at $80^{\circ} \mathrm{C}$ for $15 \mathrm{~min}$ (Botsoglou et al., 1998). Following saponification, $5 \mathrm{ml}$ hexane and $1 \mathrm{ml}$ water were added, and the mixture was vortex-mixed and centrifuged at $2000 \mathrm{~g}$. An aliquot of the upper phase was evaporated to dryness to be further reconstituted in methanol and injected into a liquid chromatograph (Shimadzu, Model 6AV, Tokyo, Japan). Liquid chromatography was carried out using a Nucleosil $\mathrm{C}_{18}, 5 \mathrm{~mm}, 250$ $\times 4.6 \mathrm{~mm}$, column (Reading, UK), and a mobile phase of methanol/water $(97: 3, \mathrm{v} /$ v) that was delivered to the system at a flow rate of $2 \mathrm{ml} / \mathrm{min}$ (Sheehy et al., 1994). A fluorimetric detector set at an excitation wavelength of $290 \mathrm{~nm}$ and emission wavelength of $330 \mathrm{~nm}$ was used for monitoring column effluents. Detector signals were quantified using peak heights and a standard calibration curve.

\section{Statistical analysis}

Each subgroup served as the experimental unit in the statistical analysis of all data. Data were subjected to analysis of variance (ANOVA) in the general linear model using the SPSS 10.05 statistical package (SPSS Ltd., Woking, Surrey, UK). The homogeneity of the variances was tested by Levene's test. When significant treatment effects were disclosed at the probability level of $\mathrm{P}<0.05$, Tukey's test was applied in order to determine statistical differences between means. Mortality values were tested by the Chi-square test. 


\section{RESULTS}

At the age of 42 days, the OR5 and OR5-TOC groups presented body weight gain values that were significantly better $(\mathrm{P}<0.05)$ than the negative control group but similar $(\mathrm{P}>0.05)$ to that of the FLA-LAS group, which was the

TABLE 2

Cumulative body weight gain (BWG), feed intake (FI) and feed conversion ratio (FCR) values of broiler chickens in response to diet and age

\begin{tabular}{|c|c|c|c|c|c|c|c|c|c|}
\hline $\begin{array}{l}\text { Age of- } \\
\text { chickens }\end{array}$ & $\begin{array}{l}\text { Nega- } \\
\text { tive } \\
\text { control }^{1}\end{array}$ & OR5 & OR10 & $\begin{array}{l}\text { OR5- } \\
\text { TOC }\end{array}$ & $\begin{array}{l}\text { OR10- } \\
\text { TOC }\end{array}$ & TOC & $\begin{array}{c}\text { FLA- } \\
\text { LAS } \\
\text { positive } \\
\text { control }\end{array}$ & $\begin{array}{c}\text { Pooled } \\
\text { SEM }\end{array}$ & $\begin{array}{c}\mathrm{P} \\
\text { Value }\end{array}$ \\
\hline \multicolumn{10}{|l|}{7 days } \\
\hline BWG, g & 119 & 124 & 129 & 126 & 121 & 122 & 123 & 1.7 & 0.169 \\
\hline FI, $g$ & 121 & 123 & 129 & 127 & 122 & 124 & 124 & 1.4 & 0.725 \\
\hline FCR & 1.02 & 0.99 & 1.01 & 1.01 & 1.01 & 1.02 & 1.01 & 0.004 & 0.806 \\
\hline \multicolumn{10}{|l|}{14 days } \\
\hline BWG, g & 309 & 335 & 329 & 326 & 327 & 332 & 324 & 3.7 & 0.985 \\
\hline FI, g & 349 & 372 & 368 & 365 & 366 & 368 & 360 & 5.2 & 0.956 \\
\hline FCR & 1.13 & 1.11 & 1.12 & 1.12 & 1.12 & 1.11 & 1.11 & 0.004 & 0.874 \\
\hline \multicolumn{10}{|l|}{21 days } \\
\hline BWG, g & 661 & 725 & 714 & 699 & 720 & 711 & 719 & 7.4 & 0.277 \\
\hline FI, g & 910 & 971 & 971 & 951 & 972 & 960 & 978 & 11.2 & 0.775 \\
\hline FCR & 1.40 & 1.34 & 1.36 & 1.36 & 1.35 & 1.35 & 1.36 & 0.004 & 0.231 \\
\hline \multicolumn{10}{|l|}{28 days } \\
\hline BWG, g & 1.079 & 1.159 & 1.099 & 1.094 & 1.129 & 1.099 & 1.109 & 8.6 & 0.224 \\
\hline FI, $\mathrm{g}$ & 1.662 & 1.715 & 1.648 & 1.652 & 1.682 & 1.659 & 1.663 & 15.2 & 0.948 \\
\hline FCR & 1.55 & 1.48 & 1.50 & 1.51 & 1.49 & 1.51 & 1.50 & 0.006 & 0.141 \\
\hline \multicolumn{10}{|l|}{35 days } \\
\hline BWG, $g$ & $1.474^{\mathrm{a}}$ & $1.624^{b c}$ & $1.554^{\mathrm{ac}}$ & $1.619^{\mathrm{bc}}$ & $1.544^{\mathrm{ac}}$ & $1.549^{\mathrm{ac}}$ & $1.579^{\mathrm{bc}}$ & 13.1 & 0.013 \\
\hline FI, $\mathrm{g}$ & 2.506 & 2.631 & 2.564 & 2.671 & 2.532 & 2.540 & 2.605 & 21.5 & 0.601 \\
\hline FCR & $1.70^{\mathrm{a}}$ & $1.62^{\mathrm{bc}}$ & $1.65^{\mathrm{ac}}$ & $1.65^{\mathrm{ac}}$ & $1.64^{\mathrm{ac}}$ & $1.64^{\mathrm{ac}}$ & $1.65^{\mathrm{ac}}$ & 0.006 & 0.003 \\
\hline \multicolumn{10}{|l|}{42 days } \\
\hline BWG, g & $1.869^{\mathrm{a}}$ & $2.119^{\mathrm{bc}}$ & $1.979^{\mathrm{ac}}$ & $2.109^{\mathrm{bc}}$ & $1.999^{\mathrm{ac}}$ & $1.944^{\mathrm{ac}}$ & $2.089^{\mathrm{bc}}$ & 23.4 & 0.005 \\
\hline FI, g & 3.532 & 3.772 & 3.641 & 3.775 & 3.658 & 3.538 & 3.760 & 39.2 & 0.513 \\
\hline FCR & $1.89^{\mathrm{a}}$ & $1.78^{\mathrm{bc}}$ & $1.84^{\mathrm{ac}}$ & $1.79^{\mathrm{bc}}$ & $1.83^{\mathrm{ac}}$ & $1.82^{\mathrm{ac}}$ & $1.80^{\mathrm{bc}}$ & 0.009 & 0.003 \\
\hline
\end{tabular}

1 negative control = group fed on basal diets containing $30 \mathrm{mg} \alpha$-tocopheryl acetate/kg feed; OR5= group fed on basal diets supplemented further with $5 \mathrm{~g}$ oregano $/ \mathrm{kg}$ feed; OR $10=$ group fed on basal diets supplemented further with $10 \mathrm{~g}$ oregano $/ \mathrm{kg}$ feed; OR5-TOC $=$ group fed on basal diets supplemented further with $5 \mathrm{~g}$ oregano/ $\mathrm{kg}$ plus an extra $170 \mathrm{mg} / \mathrm{kg} \alpha$ - tocopheryl acetate/feed; OR10-TOC $=$ group fed on basal diets supplemented further with $10 \mathrm{~g}$ oregano/kg plus an extra $170 \mathrm{mg} / \mathrm{kg} \alpha$-tocopheryl acetate/feed; TOC $=$ group fed on on basal diets supplemented further with $\alpha$-tocopheryl acetate at an extra of $170 \mathrm{mg} / \mathrm{kg}$; FLA-LAS positive control $=$ group fed on basal diets supplemented further with flavomycin at $4 \mathrm{mg} / \mathrm{kg}$ plus lasalocid at $75 \mathrm{mg} / \mathrm{kg}$ feed a,b,c values in the same row with a superscript in common do not differ significantly at $\mathrm{P}>0.05$ 
positive control group in this investigation. This indicated that oregano given as a single supplement at the level of $5 \mathrm{~g} / \mathrm{kg}$ or in combination with $\alpha$-tocopheryl acetate could serve as an alternative to the approved feed additives flavomycin and lasalocid. The OR10, OR10-TOC and TOC groups presented body weight gain values that were numerically lower than the OR5, OR5-TOC and FLA-LAS groups, and numerically higher than the negative control group, but the difference was not statistically significant (Table 2).

Incorporation of dehydrated oregano plants in the diets influenced neither $(\mathrm{P}>0.05)$ chicken mortality (Table 3 ) nor total feed intake but had a significant $(\mathrm{P}<0.05)$ effect on feed conversion ratio. Thus, at the age of 42 days, the OR5, OR5-TOC and FLA-LAS groups presented feed conversion ratios that were significantly better $(\mathrm{P}<0.05)$ than the negative control group. The OR10, OR10TOC and TOC groups presented ratios that were not statistically different from those of other groups (Table 2).

TABLE 3

Mortality of broiler chickens in response to diet and age, $\%$

\begin{tabular}{lcccccc}
\hline \multirow{2}{*}{ Groups $^{1}$} & \multicolumn{7}{c}{ Mortality, \% } \\
\cline { 2 - 7 } & 7 days & 14 days & 21 days & 28 days & 35 days & 42 days \\
\hline Control & 1.3 & 1.5 & 1.6 & 1.8 & 2.5 & 3.1 \\
OR5 & 1.2 & 1.5 & 1.7 & 1.8 & 2.1 & 2.4 \\
OR10 & 1.3 & 1.4 & 1.6 & 1.9 & 2.2 & 2.4 \\
OR5-TOC & 1.3 & 1.6 & 1.8 & 2.1 & 2.3 & 2.5 \\
OR10-TOC & 1.4 & 1.6 & 1.9 & 2.0 & 2.2 & 2.4 \\
TOC & 1.2 & 1.3 & 1.6 & 1.9 & 2.1 & 2.7 \\
FLA-LAS & 1.3 & 1.5 & 1.6 & 1.8 & 2.0 & 2.3 \\
\multicolumn{1}{c}{ P value } & 0.966 & 0.872 & 0.807 & 0.967 & 0.707 & 0.358 \\
\hline
\end{tabular}

${ }^{1}$ identification of groups as in Table 2

The iron-induced lipid oxidation experiment showed that dietary oregano improved the oxidative stability of the produced breast and thigh muscle tissues (Figure 1). The OR5 group presented MDA values that were significantly lower $(\mathrm{P}<0.05)$ than the OR10 group, which, in turn, presented MDA values that were significantly lower $(\mathrm{P}<0.05)$ than the control group. The OR10-TOC, TOC and OR5-TOC groups presented MDA values that were significantly lower $(\mathrm{P}<0.05)$ than the OR10 and the OR5 groups for both breast and thigh samples. The OR5TOC group presented MDA values that were significantly lower $(\mathrm{P}<0.05)$ than the TOC group at $270 \mathrm{~min}$. The TOC group, in turn, presented MDA values that were significantly lower $(\mathrm{P}<0.05)$ than the OR10-TOC group at $180 \mathrm{~min}$ and 270 min of incubation (Figure 1). The FLA-LAS group was not examined for MDA values because the antibacterial growth promoter flavomycin and the ionophore 
a

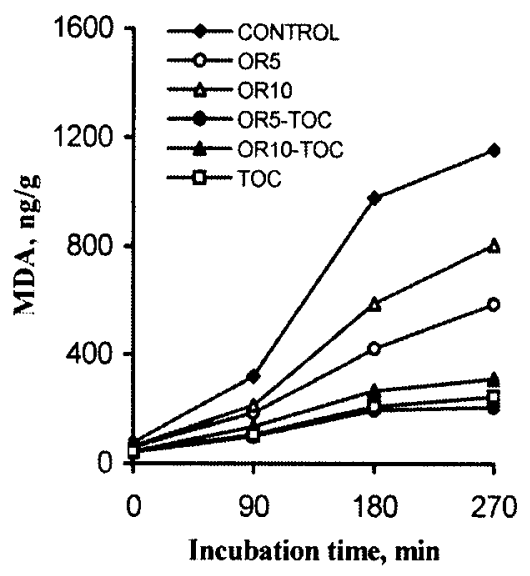

c

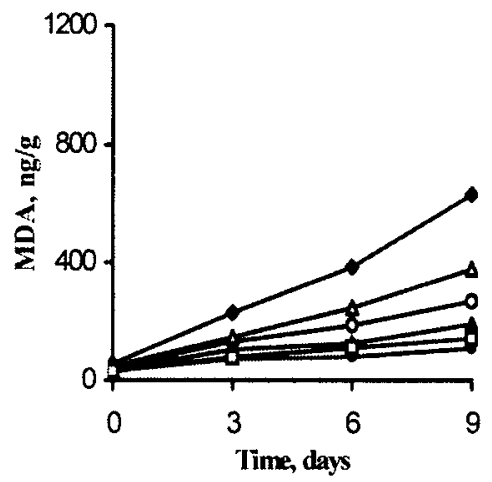

b

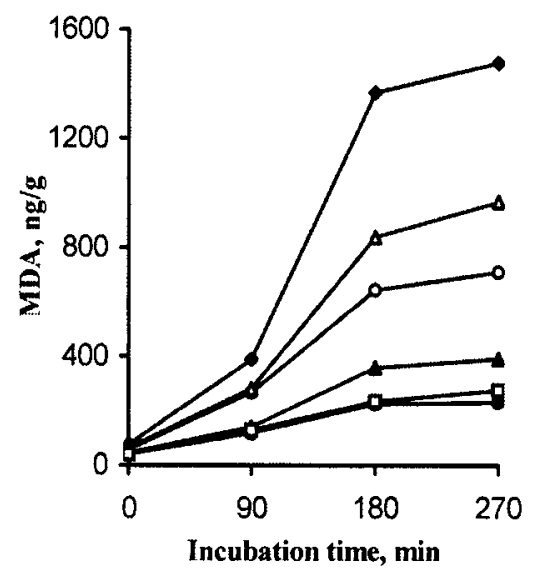

d

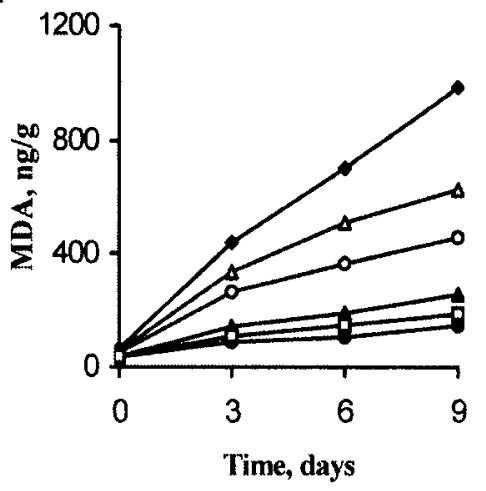

Figure 1. Mean malondialdehyde (MDA) levels in breast $(a, c)$ and thigh $(b, d)$ tissues submitted to iron-induced $(a, b)$ or refrigerated-storage-induced $(c, d)$ lipid oxidation. All data points are mean MDA concentrations from three analyses. Identification of groups as in Table 2

coccidiostat lasalocid were not expected to influence the oxidative stability of chicken meat.

The refrigerated-storage-induced lipid oxidation experiment showed an analogous lipid oxidation profile. Again, the OR5-TOC group presented MDA values that that were significantly lower $(\mathrm{P}<0.05)$ than the TOC and OR10-TOC groups (Figure 1).

Both experiments showed that thigh muscle samples were more readily susceptible to oxidation than breast samples under any dietary treatment. However, thigh muscle samples were found to contain markedly higher levels of $\alpha$-tocopherol than breast samples (Table 4). In the control group that had been 
supplemented with $30 \mathrm{mg} \alpha$-tocopheryl acetate $/ \mathrm{kg}$, mean $\alpha$-tocopherol levels in thigh and breast samples were 3.84 and $2.25 \mu \mathrm{g} / \mathrm{g}$, respectively. Supplementing the basal diet with $170 \mathrm{mg} / \mathrm{kg} \alpha$-tocopheryl acetate increased the levels of $\alpha$ tocopherol in thigh and breast samples to 19.2 and $10.4 \mu \mathrm{g} / \mathrm{g}$, respectively. The incorporation of dehydrated oregano plants in diets did not significantly $(\mathrm{P}>0.05)$ influence the level of $\alpha$-tocopherol in feeds and tissues; the OR5-TOC, OR10TOC and TOC groups presented $\alpha$-tocopherol levels that did not differ $(\mathrm{P}>0.05)$ significantly in their $\alpha$-tocopherol content (Table 4). The FLA-LAS group was not analyzed for $\alpha$-tocopherol because flavomycin and lasalocid were not expected to influence the $\alpha$-tocopherol content of chicken meat.

TABLE 4 $\alpha$-Tocopherol concentrations in finisher diet and in breast and thigh muscle tissues of broiler chickens in response to dietary supplementation with oregano and/or $\alpha$-tocopheryl acetate

\begin{tabular}{lccc}
\hline \multirow{2}{*}{ Group $^{2}$} & \multicolumn{3}{c}{$\alpha$-Tocopherol concentrations, $\mu \mathrm{g} / \mathrm{g}^{1}$} \\
\cline { 2 - 4 } & finisher diet & thigh muscle tissue & breast muscle tissue \\
\hline Control & $60^{\mathrm{a}}$ & $3.84^{\mathrm{a}}$ & $2.25^{\mathrm{a}}$ \\
OR5 & $62^{\mathrm{a}}$ & $3.95^{\mathrm{a}}$ & $2.37^{\mathrm{a}}$ \\
OR10 & $63^{\mathrm{a}}$ & $3.86^{\mathrm{a}}$ & $2.28^{\mathrm{a}}$ \\
OR5-TOC & $216^{\mathrm{b}}$ & $19.8^{\mathrm{b}}$ & $11.1^{\mathrm{b}}$ \\
OR10-TOC & $218^{\mathrm{b}}$ & $18.0^{\mathrm{b}}$ & $9.2^{\mathrm{b}}$ \\
TOC & $215^{\mathrm{b}}$ & $19.2^{\mathrm{b}}$ & $10.4^{\mathrm{b}}$ \\
Pooled SEM & 18.8 & 1.82 & 0.98 \\
$\mathrm{P} \quad$ value & 0.000 & 0.000 & 0.000 \\
\hline
\end{tabular}

${ }^{1}$ values are means of three analyses performed in duplicate

2 identification of groups as in Table 2

${ }^{a, b}$ values in the same column with a superscript in common do not differ significantly at $\mathrm{P}>0.05$

\section{DISCUSSION}

The results of the present study showed that the dehydrated oregano plants improved growth performance when incorporated in the broiler diets at the level of $5 \mathrm{~g} / \mathrm{kg}$; supplementation of the diets at this level resulted in significantly better $(\mathrm{P}<0.05)$ body weight gain and feed conversion ratio. These results are in line with studies reporting that oregano essential oil improved the performance of chickens when supplemented through drinking water at 150 or $300 \mathrm{mg} / 1$ (Basset, 2000; Hertrampf, 2001). Alcicek et al. (2003) also reported that dietary supplementation of an essential oil combination from 6 herbs including oregano improved chicken performance. However, other pertinent studies showed that supplementation of poultry diets with oregano essential oil at levels of 50 and $100 \mathrm{mg} / \mathrm{kg}$ for 
broilers (Botsoglou et al., 2002a), and at levels of 100 and $200 \mathrm{mg} / \mathrm{kg}$ for turkeys (Papageorgiou et al., 2003), had no beneficial effect on growth performance.

These inconsistent results might be attributed to differences in the environmental conditions and/or the composition of the oregano supplement. It is generally accepted that well-nourished healthy chickens do not respond to growth promoting supplements when they are housed under clean, disinfected conditions and moderate stocking density. Consequently, little or no response can be expected at high performances, but with a substandard performance the response to oregano may increase. Furthermore, oregano plants, apart from the volatile antimicrobial compounds occurring in the essential oil (Adam et al., 1998), also contain a variety of glycosidically bound volatile and non-volatile constituents that exhibit biological activity after enzymatic or acid hydrolysis (Milos et al., 2000). Therefore, oregano plants are expected to be more biologically active than the essential oil when incorporated in chicken diets.

Although the dehydrated oregano plants improved growth performance when incorporated in diets at the level of $5 \mathrm{~g} / \mathrm{kg}$, they were found to be inactive at the supplementation level of $10 \mathrm{~g} / \mathrm{kg}$. This might possibly be due to the action of the phenolic constituents that might have toxic effects in high doses. Phenolic compounds may exert their activity on the host enterocytes too (Weber and De Bont, 1996). In other words, carvacrol and thymol might have the same effect on the upper layer of mature enterocytes of the intestinal mucosa, which are already affected by the intracellular pathogens. The hydrophobic character of carvacrol suggests interaction with the membranes (Sikkema et al., 1994). When the concentration of carvacrol increases, more of this compound is expected to accumulate and interact in the phospholipid bilayer, affecting membrane fluidity (Weber and De Bont, 1996).

Since oregano plants are generally characterized by a high content of phenolic antioxidants (Economou et al., 1991), the effect of their incorporation in broiler diets on the oxidative stability of the produced meat was investigated. Evaluation of the oxidative stability of the produced chicken meat was carried out using a model system with iron-induced lipid oxidation (Botsoglou et al., 2002a). Ironinduced lipid oxidation is an accelerated approach for studying the oxidative stability of meat. Figure 1 shows that the use of this process resulted in different concentrations of MDA in breast and thigh meat. The increase was higher in the control group and lower in the TOC group. Diet supplementation with oregano plants decreased, in general, MDA values in tissue samples compared with the control, a finding suggesting that dietary oregano exerted a significant antioxidant effect. The OR5-TOC group presented MDA values that were significantly lower $(\mathrm{P}<0.05)$ than the TOC and OR10-TOC groups, a finding suggesting that there might be a synergic antioxidative effect of a dietary oregano level 
of $5 \mathrm{~g} / \mathrm{kg}$ with $\alpha$-tocopheryl acetate. An analogous lipid oxidative profile was observed when chicken meat was refrigerated stored at $4^{\circ} \mathrm{C}$ for 9 days. These results are in agreement with recent studies showing that diet supplementation with oregano essential oil has the potential to increase the oxidative stability of chicken (Botsoglou et al., 2002a,b, 2003a) and turkey (Botsoglou et al., 2003b,c; Papageorgiou et al., 2003) tissues.

The lower MDA values found in tissues after diet supplementation with dehydrated oregano plants and $\alpha$-tocopheryl acetate are probably the result of various antioxidant constituents that entered the circulatory system, were distributed and retained in the tissues, exhibiting antioxidant activity. The bioavailability of oregano constituents in chicken tissues cannot be directly demonstrated because adequate analytical methodology has not been developed yet. However, it has been reported that $\alpha$-tocopherol, a major natural chainbreaking antioxidant in the cell membranes, provides protection against early events in lipid oxidation at the site where it is initiated, while oregano constituents can be effective in the inhibition of all phases of the peroxidative process by first neutralising free radicals, then blocking peroxidation catalysis by iron and, finally, through chain-breaking activity (Cervato et al., 2000). A synergistic effect of dietary oregano essential oil and $\alpha$-tocopheryl acetate supplementation on the oxidative stability of raw and cooked turkey meat has also been previously reported by Botsoglou et al. (2003c). These results are in line with the findings of Fang and Wada (1993) who found that a mixture of $\alpha$-tocopherol and an extract of rosemary, another plant of the Labiatae family, exerted a stronger antioxidant effect than either $\alpha$-tocopherol or rosemary alone, in a sardine model system; the synergistic action of rosemary was attributed to possible regeneration of $\alpha$ tocopherol through donation of hydrogen atoms to the tocopheroxyl radicals.

Dietary supplementation with oregano at levels of 5 or $10 \mathrm{~g} / \mathrm{kg}$, did not increase ( $\mathrm{P}>0.05$ ) the concentration of $\alpha$-tocopherol in muscle tissues (Table 4). Comparing the lipid oxidation profiles of breast and thigh muscle samples, it appears that the latter suffered more intense lipid oxidation. Since the greater the amount of endogenous $\alpha$-tocopherol in tissues, the better protection the muscle should have against oxidative attack, breast and thigh muscle samples were submitted to $\alpha$ tocopherol analysis. It was found that thigh muscle contained markedly higher $\alpha$-tocopherol levels than breast muscle although it tended to oxidize faster than breast muscle. The results on $\alpha$-tocopherol concentrations in chicken tissues are in agreement with values reported in the literature for poultry (Sheehy et al., 1994; Botsoglou et al., 2002a,b).

The higher susceptibility of thigh muscle to oxidation has been attributed to its higher content of polyunsaturated fatty acids with more than two double bonds (Jensen et al., 1997). Although breast muscle has a higher percentage of 
these acids in fat, the absolute amount in thigh muscle is three times higher than in breast muscle regardless of the dietary treatment because the total fat content in thigh muscle is approximately five times that of breast muscle (Jensen et al., 1997). It appears that the molar ratio of these fatty acids to $\alpha$-tocopherol is more descriptive than the level of muscle $\alpha$-tocopherol alone (Jensen et al., 1997). The large amount of pro-oxidative agents originating from tissue myoglobin and other iron containing proteins found in thigh muscle may also reduce the oxidative stability in this tissue (Rhee and Ziprin, 1987). Muscle $\alpha$-tocopherol is one important factor influencing the level of lipid oxidation, but the influence of polyunsaturated fatty acids and content of pro-oxidants must be taken into consideration as well.

\section{CONCLUSIONS}

The results presented in this study showed that the dehydrated oregano plants exerted a growth-promoting effect when incorporated in chicken diets at the level of $5 \mathrm{~g} / \mathrm{kg}$. This incorporation also improved the oxidative stability of both breast and thigh muscle, the level of $5 \mathrm{~g} / \mathrm{kg}$ again being more effective compared with $10 \mathrm{~g} / \mathrm{kg}$. The oxidative stability offered by oregano plants was inferior to that exhibited by the $\alpha$-tocopheryl acetate supplementation. However, the dietary combination of $5 \mathrm{~g} / \mathrm{kg}$ oregano and $\alpha$-tocopheryl acetate exhibited antioxidant activity higher than that presented by $\alpha$-tocopheryl acetate when supplemented alone or in combination with $10 \mathrm{~g} / \mathrm{kg}$ oregano. Thigh muscle was more susceptible to oxidation than breast muscle, although the former contained $\alpha$-tocopherol at markedly higher levels. It may, therefore, be assumed that antioxidant compounds of oregano were absorbed from the diet, entered the circulatory system after ingestion, and were distributed and retained in muscle and other tissues. As there is no analytical method available for the determination of oregano antioxidants in meat, the bioavailability of these compounds in the dietary-modified meat could not be directly demonstrated. Additional research is needed toward developing a method that could identify and quantify each of the main antioxidant constituents of oregano deposited into chicken meat.

\section{ACKNOWLEDGEMENTS}

The authors would like to thank the Animal Feed Company, Triantafillou Bross, SA, Thessaloniki, Greece, for supporting the present research by kindly donating the broiler feeds. 


\section{REFERENCES}

Adam K., Sivropoulou A., Kokkini S., Lanaras T., Arsenakis M., 1998. Antifungal activities of Origanum vulgare ssp. hirtum, Mentha spicata, Lavandula angustifolia, and Salvia fruticosa essential oils against human pathogenic fungi. J. Agr. Food Chem. 46, 1739-1745

Alcicek A., Bozkurt M., Cabuk M., 2003. The effect of an essential oil combination derived from selected herbs growing wild in Turkey on broiler performance. S. Afr. J. Anim. Sci. 33, 89-94

Basset R., 2000. Oregano positive impact on poultry production. World Poultry 16, 31-34

Botsoglou N.A., Christaki E., Fletouris D.J., Florou-Paneri P., Spais A.B., 2002b. The effect of dietary oregano essential oil on lipid oxidation in raw and cooked chicken during refrigerated storage. Meat Sci. 62, 259-265

Botsoglou N.A., Fletouris D.J., Florou-Paneri P., Christaki E., Spais A.B., 2003a. Inhibition of lipid oxidation in long-term frozen stored chicken meat by dietary oregano essential oil and $\alpha$ tocopheryl acetate supplementation. Food Res. Int. 36, 207-213

Botsoglou N.A., Fletouris D.J., Papageorgiou G.E., Vassilopoulos V.N., Mantis A.J., Trakatellis A.G., 1994. A rapid, sensitive, and specific thiobarbituric acid method for measuring lipid peroxidation in animal tissues, food, and feedstuff samples. J. Agr. Food Chem. 42, 1931-1937

Botsoglou N., Fletouris D., Psomas I., Mantis A., 1998. Rapid gas chromatographic method for simultaneous determination of cholesterol and tocopherol in eggs. J. AOAC Int. 81, 1177-1183

Botsoglou N.A., Florou-Paneri P., Christaki E., Fletouris D.J., Spais A.B., 2002a. Effect of dietary oregano essential oil on performance of chickens and on iron-induced lipid oxidation of breast, thigh and abdominal fat tissues. Brit. Poultry Sci. 43, 223-230

Botsoglou N.A., Govaris A., Botsoglou E.N., Grigoropoulou S.H., Papageorgiou G., 2003b. Antioxidant activity of dietary oregano essential oil and $\alpha$-tocopheryl acetate supplementation in long-term frozen stored turkey meat. J. Agr. Food Chem. 51, 2930-2936

Botsoglou N.A., Grigoropoulou S.H., Botsoglou E., Govaris A., Papageorgiou G., 2003c. The effects of dietary oregano essential oil and $\alpha$-tocopheryl acetate on lipid oxidation in raw and cooked turkey during refrigerated storage. Meat Sci. 65, 1193-1200

Cervato G., Carabelli M., Gervasio S., Cittera A., Cazzola R., Cestaro B., 2000. Antioxidant properties of oregano (Origanum vulgare) leaf extracts. J. Food Biochem. 24, 453-465

Committee on Care and Use of Laboratory Animals, 1996. Guide for the Care and Use of Laboratory Animals. Institute of Laboratory Animal Resources, Commission on Life Sciences, National Research Council, National Academy Press, Washington, DC

Economou K.D., Oreopoulou V., Thomopoulos C.D., 1991. Antioxidant properties of some plant extracts of the Labiatae family. J. Amer. Oil Chem. Soc. 68, 109-113

European Commission Regulation (EC) No 97/6 of 30 January 1997 amending Council Directive 70/524/EC concerning additives in feedingstuffs, OJ L 96, 28/3/1998:39

Fang X., Wada S., 1993. Enhancing the antioxidant effect of $\alpha$-tocopherol with rosemary in inhibiting catalyzed oxidation caused by $\mathrm{Fe}^{2}$ and hemoprotein. Food Res. Int. 26, 405-411

Florou-Paneri P., Christaki E., Giannenas I.A., Papazahariadou M., Botsoglou N.A., Spais A.B., 2004. Effect of dietary Olympus tea (Sideritis scardica) supplementation on performance of chickens challenged with Eimeria tenella. J. Anim. Feed Sci. 13, 301-311

Giannenas I., Florou-Paneri P., Papazahariadou M., Botsoglou N.A., Christaki E., Spais A.B., 2004. Effect of diet supplementation with ground oregano on performance of broiler chickens challenged with Eimeria tenella. Arch. Geflügelk. 68, 247-252

Hargis P.S., Van Elswyk M.E., 1993. Manipulating the fatty acid composition of poultry meat and eggs for the health conscious consumer. World Poultry Sci. J. 49, 251-264

Hertrampf J.W., 2001. Alternative antibacterial performance promoters. Poultry Int. 40, 50-52 
Jensen C., Guidera J., Skovgaard I.M., Staun H., Skibsted L.H., 1997. Effects of dietary $\alpha-$ tocopheryl acetate supplementation on $\alpha$-tocopherol deposition in porcine m. psoas major and $\mathrm{m}$. longissimus dorsi and on drip loss. Color stability of pork meat. Meat Sci. 45, 491-500

Lopez-Bote C.J., Gray J.I., Gomaa E.A., Flegal C.J., 1998. Effect of dietary administration of oil extracts from rosemary and sage on lipid oxidation in broiler meat. Brit. Poultry Sci. 39, 235-240

Milos M., Mastelic J., Jerkovic I., 2000. Chemical composition and antioxidant effect of glycosidically bound volatile compounds from oregano (Origanum vulgare L. spp. hirtum). Food Control 71, 79-83

Papageorgiou G., Botsoglou N., Govaris A., Giannenas I.A., Iliadis S., Botsoglou E., 2003. Effect of dietary oregano oil and $\alpha$-tocopheryl acetate supplementation on iron-induced lipid oxidation of turkey breast, thigh, liver and heart tissues. J. Anim. Physiol. Anim. Nutr. 87, 324-335

Rhee K.S., Ziprin Y.A., 1987. Lipid oxidation in retail beef, pork and chicken muscles as affected by concentrations of heme pigments and nonheme iron and liposomal enzymic peroxidation activity. J. Food Biochem. 11, 1-15

Sheehy P.J.A., Morrisey P.A., Flynn A., 1994. Consumption of thermally-oxidised sunflower oil by chicks reduces $\alpha$-tocopherol status and increases susceptibility of tissues to lipid oxidation. Brit. J. Nutr. 71, 53-65

Sikkema J., De Bont J.A.M., Poolman B., 1994. Interactions of cyclic hydrocarbons biological membranes. J. Biol. Chem. 11, 8022-8028

Tang S.Z., Kerry J.P., Sheeham D., Buckley D.J., Morrissey P.A., 2000. Dietary tea catechins and iron-induced lipid oxidation in chicken meat, liver and heart. Meat Sci. 56, 285-290

Weber F.J., De Bont J.A.M., 1996. Adaptation mechanisms of microorganisms to the toxic effects of organic solvents on membranes. Biochim. Biophys. Acta 1286, 225-245

Wegener H.C., Aarestrup F.M., Jensen L.B., Hammerum A.M., Bager F., 1998. The association between the use of antimicrobial growth promoters and development of resistance in pathogenic bacteria towards growth promoting and therapeutic antimicrobials. Anim. Feed Sci. Tech. 7, 7-14

\section{STRESZCZENIE}

Wpływ dodatku do paszy oregano i/lub octanu $\alpha$-tokoferolu na rozwój kurcząt brojlerów oraz oksydatywną stabilność mięsa

Doświadczenie przeprowadzono na 6300-jednodniowych Cobb-500 kurczętach, podzielonych losowo do 7 grup, z trzema podgrupami po 150 kogutków i 150 kurek. Kurczętom grupy negatywnej kontrolnej podawano dawkę podstawową zawierająca $30 \mathrm{mg}$ octanu $\alpha$-tokoferolu $/ \mathrm{kg}$ paszy, w pozostałych grupach zastosowano następujące dodatki: suszone oregano $\mathrm{w}$ ilości 5 grupa (OR5) lub $10 \mathrm{~g} / \mathrm{kg}$ (OR10), 5 lub $10 \mathrm{~g}$ suszonego oregano $/ \mathrm{kg}+170 \mathrm{mg}$ octanu $\alpha$-tokoferolu, grupy OR5 -TOC i OR10-TOC, odpowiednio, $170 \mathrm{~g} / \mathrm{kg}$ octanu $\alpha$-tokoferolu (grupa TOC), oraz 4 $\mathrm{mg} / \mathrm{kg}$ flawomycyny $+75 \mathrm{mg} / \mathrm{kg}$ lasalocidu (grupa kontrolna pozytywna, FLA-LAS). Na podstawie wyników 42-dniowego żywienia (m.c., dzienne przyrosty i wykorzystanie paszy) stwierdzono, że dodatek $5 \mathrm{~g} / \mathrm{kg}$ samego oregano lub w kombinacji z octanem $\alpha$-tokoferolu może zastapić takie dodatki jak flawomycyna i lasalocid, jako stymulatory wzrostu. Dodatek $5 \mathrm{~g} / \mathrm{kg}$ oregano okazał się bardziej skuteczny niż $10 \mathrm{~g}$ jako czynnik przeciw utlenianiu tłuszczu. Najlepsze wyniki związane $\mathrm{z}$ antyoksydacyjną aktywnością oregano uzyskano przy jego dawce $5 \mathrm{~g} / \mathrm{kg}$ w kombinacji z octanem $\alpha$-tokoferolu. Stwierdzono również, że mięśnie udowe są bardziej podatne na utlenianie niż mięśnie piersiowe. 